Halvorson, H. \& Jackson, L. (1956). J. gen. Microbiol. 14, 26-37

\title{
The Relation of Ribose Nucleic Acid to the Early Stages of Induced Enzyme Synthesis in Yeast
}

\author{
BY H. HALVORSON AND L. JACKSON \\ Department of Bacteriology, University of Michigan, Ann Arbor, \\ Michigan, U.S.A.
}

SUMMARY: The synthesis of deoxyribonucleic acid (DNA) in yeast can be abolished by dosages of ultraviolet light (UV) which permit ribonucleic acid (RNA) and protein synthesis to continue. Those dosages of UV which inhibit $\alpha$-glucosidase synthesis prevent not only the net utilization of the free amino acid pool but also inhibit glycine incorporation into proteins and decrease to a minimal value glycine and phosphate incorporation into RNA. The latent period before the appearance of $\alpha$-glucosidase was characterized by an increased sensitivity to irradiation and certain amino acid analogues. The significance of these results in an interpretation of the early stages in enzyme induction is discussed.

Previous investigations on induced $\alpha$-glucosidase synthesis in yeast led to the conclusion that free amino acids were the precursors of the enzyme and that the first stable intermediate formed must be of sufficient complexity to involve a large percentage of these amino acids (Halvorson \& Spiegelman, 1952; Halvorson, Spiegelman \& Hinman 1955). Over the past four years a continued attempt to identify peptide intermediates by a wide variety of techniques and under various conditions had failed. We therefore accepted as a working hypothesis a template-type mechanism for the enzyme-forming system. Unfortunately such a conclusion almost leads to an impasse in attempts to design experiments to study the mechanism of enzyme synthesis. Although experiments with radioactive amino acids have proved valuable in studying protein synthesis, they have thus far given little information on the mechanism involved.

At present, it would seem profitable first to gain further information on the nature of the enzyme-forming system (EFS) itself. Two approaches for providing such information are as follows. First, the dissociation of enzyme synthesis from non-essential cellular functions. The recent separation in yeast of the EFS from the processes concerned with cell viability (Barron, Spiegelman \& Quaster, 1953), and the demonstration of enzyme synthesis in disrupted bacterial cells (Gale, 1955) illustrate the usefulness of this approach. The second approach involves an investigation of the early stages of induced enzyme synthesis. The induction of penicillinase in Bacillus cereus, which involves several distinct stages (Pollock, 1953), and the observation by Borsook (1955) that the rate of enzyme synthesis is actually very slow compared to enzymic reactions suggest the possibility of isolating stages in the synthesis of an enzyme molecule. The purpose of the present paper is to furnish additional information (Halvorson \& Jackson, 1954), by these two approaches, on the nature of the EFS in $\alpha$-glucosidase synthesis in yeast. 


\section{METHODS}

A diploid representative of Saccharomyces cerevisiae, strain LK2G12, was grown in standing flasks at $30^{\circ}$ in a complete medium prepared by adding the following to 1 l. of water: Bacto-Peptone, 5 g.; yeast extract, $2 \cdot 5 \mathrm{~g} . ; 60 \%(\mathrm{w} / \mathrm{v})$ sodium lactate, $6.0 \mathrm{ml}$.; $\mathrm{CaCl}_{2}, 0 \cdot 25 \mathrm{~g}$.; $\mathrm{MgSO}_{4} .7 \mathrm{H}_{2} \mathrm{O}, 0 \cdot 25 \mathrm{~g}$.; $\mathrm{KH}_{2} \mathrm{PO}_{4}, 2 \cdot 0 \mathrm{~g}$.; $\left(\mathrm{NH}_{4}\right)_{2} \mathrm{SO}_{4}, 6 \cdot 0 \mathrm{~g}$.; glucose, $40 \mathrm{~g}$.

Log-phase organisms (12 hr.) were harvested by centrifugation immediately before the experiment. They were washed twice in cold water and resuspended, either in water or in a nitrogen- and carbohydrate-free buffer (Halvorson \& Spiegelman, 1952) to a density of $2 \cdot 84 \mathrm{mg}$. dry wt. yeast $/ \mathrm{ml}$, , with the aid of a Klett-Summerson colorimeter.

Inductions were carried out with organisms suspended in buffer $+3 \%(w / v)$ maltose and incubated aerobically at $30^{\circ}$, either in a standard Warburg apparatus or in Erlenmeyer flasks on a rotary platform shaker. $\alpha$-Glucosidase activity was followed in intact organisms by the two-cup method (Halvorson \& Spiegelman, 1953) or by an $\alpha$-phenylglucoside assay in cell extracts (Dr S. Spiegelman, 1955, unpublished results). In the first case the amount of enzyme is proportional to the $Q_{\mathrm{CO}_{3}}^{\mathrm{o}}$ value corrected for the endogenous respiration. This procedure for assaying enzyme content was previously checked by a direct measurement of enzyme activity in cell extracts.

Irradiations with ultraviolet light (UV) were carried out on aqueous suspensions of organisms in open Petri dishes (5.5 in.), placed at a distance of $15 \mathrm{~cm}$. from a low-pressure 15 W. General Electric germicidal bulb (2537 A.). The output of the bulb $\left(55 \cdot 3 \mathrm{ergs} / \mathrm{sec} . \mathrm{mm}^{2}\right)$ was determined from the rate of bacteriophage inactivation (Luria \& Dulbecco, 1949). After irradiations the organisms were collected, washed, and resuspended to their original volume in buffer. All manipulations were conducted under a yellow light which had previously been shown not to cause photoreactivation.

The methods described by Hershey (Hershey, 1953; Hershey, Dixon \& Chase, 1953) were used for extracting the organisms and for the analysis of protein, ribonucleic acid (RNA), and deoxyribonucleic acid (DNA). Free amino acid pools were collected and analysed by the use of specific decarboxylases (Halvorson \& Spiegelman, 1952). Nucleotides of RNA were prepared (Juni, Kamen, Reiner \& Spiegelman, 1948), adsorbed on Dowex 1 columns, separated by elution (Cohen, 1950), and their phosphate contents determined (Umbreit, Burris \& Stauffer, 1949). The guanine and adenine of RNA nucleotides were separated by paper chromatography, eluted, and their concentrations determined from their extinction coefficients (Hershey et al. 1953; Dr A. D. Hershey, 1954, personal communication). Radioactivities were measured with a conventional type of end-window Geiger-Muller tube coupled to a scaling unit and a mechanical counter.

Inorganic ${ }^{32} \mathrm{P}(0.025 \mathrm{mg}$. $\mathrm{P} / \mathrm{mc}$.) was obtained from the Oak Ridge National Laboratory. Glycine-1-14C (1.21 mc./mu.) was obtained from Tracer Laboratory. Tryptozan was furnished by Dr Snyder, University of Illinois, and 2-pyridinethiol-1-oxide by Dr J. O. Lampen, Squibb Institute. 


\section{RESULTS}

Dissociation by irradiation of DNA synthesis from RNA and protein synthesis

Kelner (1953) showed that dosages of ultraviolet light which abolished DNA synthesis in Escherichia coli had little immediate effect on RNA and protein synthesis. Similar experiments were made with yeast to determine whether this relationship held with this organism. To observe readily any differences in

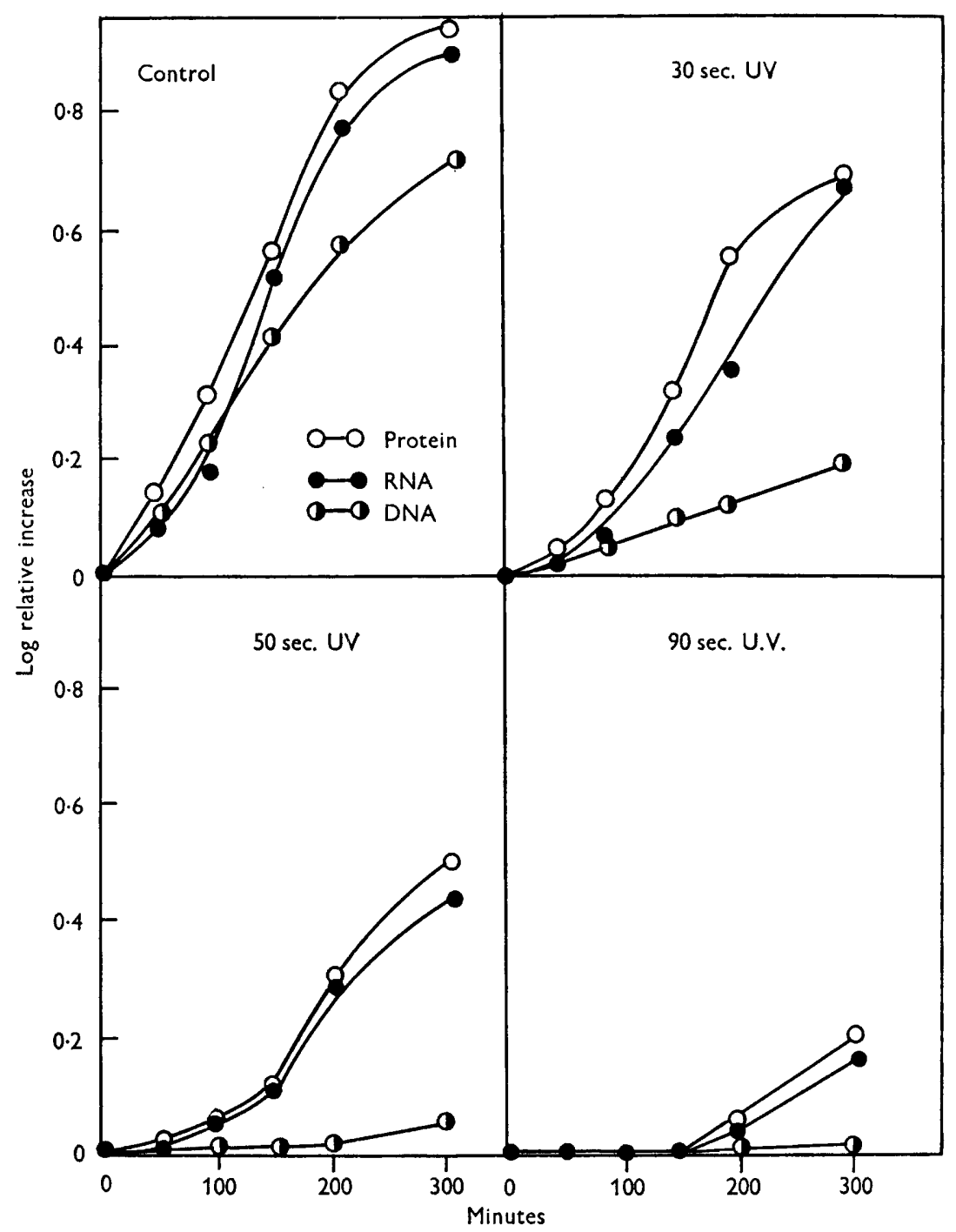

Fig. 1. Effect of UV irradiation on protein, RNA and DNA synthesis. Flasks containing $500 \mathrm{ml}$. glucose broth were each inoculated with $50 \mathrm{ml}$. of irradiated cell suspension and placed on a rotary shaker in the dark at $30^{\circ}$. 
the UV sensitivity of protein, RNA and DNA synthesis, irradiated organisms were placed in a complete growth medium. A typical experiment was carried out as follows. Log-phase organisms were suspended in water and irradiated for various intervals. At intervals samples were removed for analysis of total protein, RNA and DNA. The results (Fig. 1) indicate a close parallel between protein, DNA and RNA synthesis in the unirradiated controls. In the organisms irradiated for $\mathbf{3 0}$ or $\mathbf{5 0}$ sec., the dissociation of DNA synthesis from protein and RNA synthesis is readily evident. Both protein and RNA synthesis are sensitive to irradiation exposures of $90 \mathrm{sec}$. or more.

\section{Effect of irradiation on protein and enzyme synthesis in resting organisms}

Induced $\alpha$-glucosidase synthesis in resting organisms involves protein synthesis (Halvorson \& Spiegelman, 1952), although under the conditions of induction, the total contents of RNA and DNA are constant within experimental error. One can, however, compare enzyme and protein synthesis by examining the dosages required to prevent enzyme induction and those required to inhibit net utilization of the free amino acid pool, respectively. Washed suspensions of log-phase organisms were irradiated and divided into two parts. It is clear (Fig. 2) that an excellent parallelism is observed in the loss of the capacities to incorporate amino acids into protein and to synthesize enzyme. A dosage of 80 sec. irradiation or more was sufficient virtually to abolish the synthesis of new protein. These results cannot be attributed to an inhibition of amino acid synthesis or pool replenishment from glucose and $\mathrm{NH}_{3}$, since dosages below $1200 \mathrm{sec}$. have little or no effect on the replenishment process (Spiegelman, Halvorson \& Ben-Ishai, 1955).

It seemed desirable to examine directly the effect of irradiation on amino acid incorporation per se into total protein. The specific activities of the protein fractions are shown in Fig. 3, from which it is clear that a dosage of $70 \mathrm{sec}$. was sufficient to diminish glycine incorporation to a minimal value of $10 \%$.

\section{Effect of ultraviolet irradiation on phosphate and glycine incorporation into $\mathbf{R N A}$}

Swenson \& Giese (1950) showed that at sufficiently high dosages UV inhibited enzyme synthesis in yeast. Although the dosages required were far above those found here to be adequate for the dissociation of the effects on DNA synthesis from RNA and protein synthesis, an examination (Swenson, 1950) of the action spectrum of the inhibition of enzyme formation revealed that it coincided with the absorption spectrum of nucleic acid. Since it might be argued that the energy adsorbed by the nucleic acids is transmitted and damages some cellular processes other than RNA synthesis, it was decided to follow the effect of irradiation on the ability of RNA to incorporate ${ }^{32} \mathbf{P}$ or ${ }^{14} \mathrm{C}$.

The effect of irradiation on the incorporation of labelled phosphate into the nucleotides of RNA was examined in an experiment, the results of which 
(Table 1) indicate that rather severe effects on enzyme synthesis were achieved at dosages which had relatively little effect on the incorporation of ${ }^{32} \mathbf{P}$ into RNA. Even at the 120 sec. dose, which completely abolished enzyme synthesis and amino acid utilization, between 35 and $84 \%$ of the normal amount of

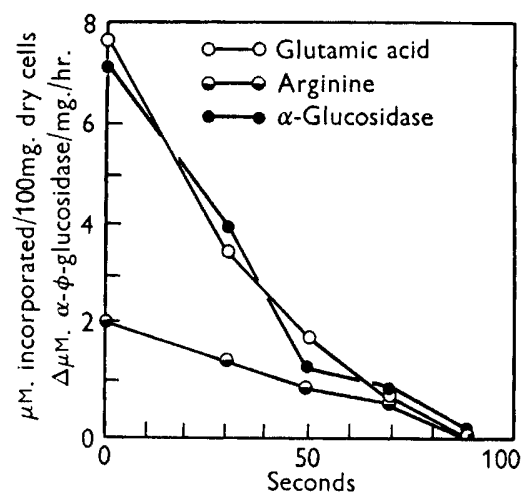

Fig. 2

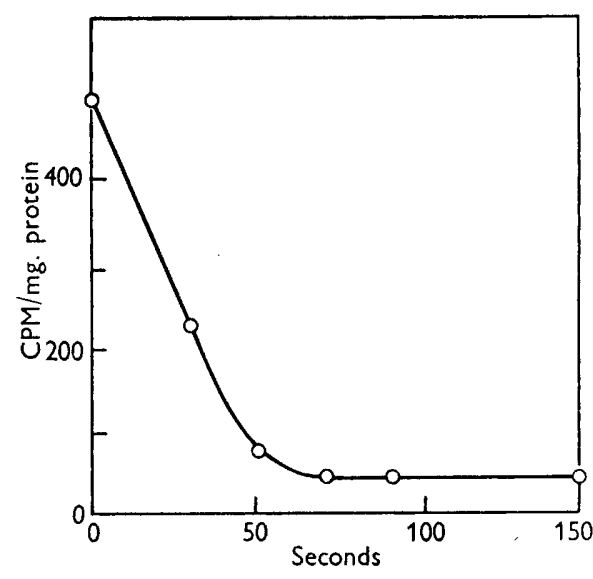

Fig. 3

Fig. 2. The effect of UV on the utilization of the free amino acid pool and $\alpha$-glucosidase synthesis in yeast. The first samples were suspended in buffer containing $3 \%(\mathrm{w} / \mathrm{v})$ glucose. After an $80 \mathrm{~min}$. aerobic incubation at $30^{\circ}$, the pools were assayed for glutamic acid and arginine by the decarboxylase methods. To examine the capacity of these organisms to form enzyme, the second lot of samples were suspended in buffer containing $3 \%(\mathrm{w} / \mathrm{v})$ maltose and incubated aerobically for $80 \mathrm{~min}$. Following induction, dried cell preparations were made, and the $\alpha$-glucosidase activity measured in the extracts by the $\alpha$-phenylglucoside method.

Fig. 3. The effect of UV irradiation on the incorporation of glycine-1-14 $\mathrm{C}$ into yeast protein. Log-phase organisms were irradiated as before and suspended to $5.68 \mathrm{mg}$. dry wt. $/ \mathrm{ml}$. in buffer containing $3 \%(\mathrm{w} / \mathrm{v})$ glucose. To $22.5 \mathrm{ml}$. samples were added $84 \mu \mathrm{g}$. glycine-1 ${ }^{-14} \mathrm{C}$. After aerobic incubation for $45 \mathrm{~min}$. at $30^{\circ}$ in the dark, the organisms were harvested, washed, disrupted with $0 \cdot 3 \mathrm{M}$-trichloroacetic acid and the protein fraction retained.

\section{Table 1. The effect of $U V$ irradiation on enzyme synthesis and ${ }^{32} \mathrm{P}$ incorporation into $R \mathbf{N A}$}

Samples $(80 \mathrm{ml}$.) of cell suspensions were each irradiated for various intervals. Ten $\mathrm{ml}$. of suspension were induced to form $\alpha$-glucosidase for $80 \mathrm{~min}$. in the presence of $3 \%(\mathrm{w} / \mathrm{v})$ maltose. The remaining organisms were suspended in $70 \mathrm{ml} . \mathrm{m} / \mathbf{1 5}$ phthalate buffer (pH 4.5) containing $\mathrm{M} / 450{ }^{32} \mathrm{PO}_{4}(0.35 \mathrm{mc}$.) and $3 \%(\mathrm{w} / \mathrm{v})$ glucose. After aerobic incubation for 80 min. at $30^{\circ}$ the nucleotides of RNA were collected and their specific activities and the total cell RNA content determined.

\begin{tabular}{|c|c|c|c|c|c|c|c|c|c|c|}
\hline \multirow{2}{*}{$\begin{array}{c}\text { UV } \\
\text { dose } \\
\text { (sec.) }\end{array}$} & \multirow[b]{2}{*}{$E^{*}$} & \multirow[b]{2}{*}{$\begin{array}{c}\mu \mathrm{g} . \\
\text { RNA/ml. }\end{array}$} & \multicolumn{2}{|c|}{ Cytidylic } & \multicolumn{2}{|c|}{$\overbrace{}^{\text {Adenylic }}$} & \multicolumn{2}{|c|}{$\overbrace{}^{\text {Uridylic }}$} & \multicolumn{2}{|c|}{$\overbrace{}^{\text {Guanylic }}$} \\
\hline & & & $\begin{array}{c}\text { c.p.m./ } \\
\mu \mathrm{g} . \mathbf{P}\end{array}$ & $\%$ & $\begin{array}{l}\text { c.p.m./ } \\
\mu \mathrm{g} . \mathbf{P}\end{array}$ & $\%$ & $\begin{array}{l}\text { c.p.m./ } \\
\mu \mathrm{g} . \mathbf{P}\end{array}$ & $\%$ & $\begin{array}{l}\text { c.p.m./ } \\
\mu \mathrm{g} . \mathbf{P}\end{array}$ & $\%$ \\
\hline 0 & $2 \cdot 14$ & $3 \cdot 10$ & 202 & 100 & 310 & 100 & 132 & 100 & 192 & 100 \\
\hline 30 & $1 \cdot 24$ & 2.92 & 193 & 95 & 298 & 96 & 116 & 81 & 170 & 88 \\
\hline 70 & 0.09 & $2 \cdot 92$ & 146 & 72 & 284 & 91 & 79 & 60 & 82 & 42 \\
\hline 120 & 0.00 & $3 \cdot 06$ & 128 & 63 & 263 & 84 & 48 & 37 & 68 & 35 \\
\hline
\end{tabular}


phosphate incorporation into RNA was, still observed. Within the limits of observation there was no net change in the total RNA content during the experiment.

Because the extent of incorporation is frequently a function of the labelled substrate employed (Anderson \& Aquist, 1953), the effect of irradiation on the incorporation of another component of the normal metabolic pool into RNA was examined. Glycine was chosen since it is incorporated into adenine and guanine (Edmonds, Delluva \& Wilson, 1952; Roberts, Abelson, Cowie, Bolton $\&$ Britten, 1955) and is readily assimilated into the free amino acid pool (Halvorson, Fry \& Schwemmin, 1955). In a typical experiment (Fig. 3), irradiated organisms were incubated for $45 \mathrm{~min}$. in the presence of glycine-1-14 $\mathrm{C}$. After isolation and hydrolysis of the RNA nucleotides, adenine and guanine were isolated and their specific activities determined. The dosages of UV which inhibited enzyme synthesis and amino acid incorporation (Fig. 3) severely depressed glycine incorporation into RNA (Table 2).

A discrepancy between phosphate (Table 1) and glycine incorporation (Fig. 2) has been observed in other systems (Anderson \& Aquist, 1953). This difference may represent either the ease of phosphate exchange or a hastening of RNA breakdown by UV irradiation and a preferential utilization of RNA bases for RNA synthesis as compared to de novo synthesis of purines and pyrimidines. The present data do not permit a decision between these alternatives. There appears to be a fraction, variable in the case of phosphate and $11 \%$ in the case of glycine, whose incorporation is resistant to relatively high dosages of radiation. Since it was found that irradiated organisms accumulated internally both labelled phosphate and glycine, the observed effects cannot be attributed to an inhibition of cell permeability.

Table 2. The effect of $U V$ irradiation on glycine-1-14 $\mathrm{C}$ incorporation into $R N A$

\begin{tabular}{ccccc} 
UV dose & \multicolumn{2}{c}{ Guanine } \\
(sec.) & c.p.m. $/ \mu$ mole & $\%$ & $\overbrace{\text { c.p.m. } / \mu \text { mole }}^{\text {Adenine }}$ & $\%$ \\
0 & $\mathbf{5 4 5}$ & 100 & $\mathbf{6 6 \cdot 5}$ & 100 \\
30 & 167 & $\mathbf{3 0 \cdot 8}$ & $\mathbf{3 5 \cdot 6}$ & $\mathbf{5 3 \cdot 3}$ \\
50 & $\mathbf{7 9}$ & $14 \cdot 5$ & $14 \cdot 1$ & $\mathbf{2 1 \cdot 1}$ \\
70 & $65 \cdot 6$ & $12 \cdot 1$ & $\mathbf{7 \cdot 5}$ & $11 \cdot 2$ \\
90 & 65 & $11 \cdot 9$ & $\mathbf{7 \cdot 0}$ & $10 \cdot 4$ \\
150 & 67 & $12 \cdot 3$ & $7 \cdot 2$ & $10 \cdot 7$
\end{tabular}

Stages in enzyme synthesis

The probable involvement of RNA in the enzyme-forming system (Spiegelman et al. 1955) leads one to inquire whether its function is required throughout the cycle of enzyme synthesis. It is clear from the work of Pollock (1953) that penicillinase induction in Bacillus cereus involves several stages. In the first stage of primary interaction, a $60 \mathrm{sec}$. exposure to penicillin permits a subsequent linear production of enzyme, whose rate depends on the amount of bound penicillin (Pollock effect). This is followed by a $14 \mathrm{~min}$. latent stage which is characterized by a UV sensitivity. The subsequent active stage of 
enzyme synthesis is relatively insensitive to UV irradiation. Attempts to demonstrate clearly a Pollock effect in $\alpha$-glucosidase synthesis in yeast thus far have not been encouraging, although a latent stage can be demonstrated. It is evident (fig. 4) that the UV sensitivity is related to the time of irradiation. When cells are irradiated for $80 \mathrm{sec}$. immediately before or after addition of the inducer, enzyme synthesis is completely inhibited. The same dosage of

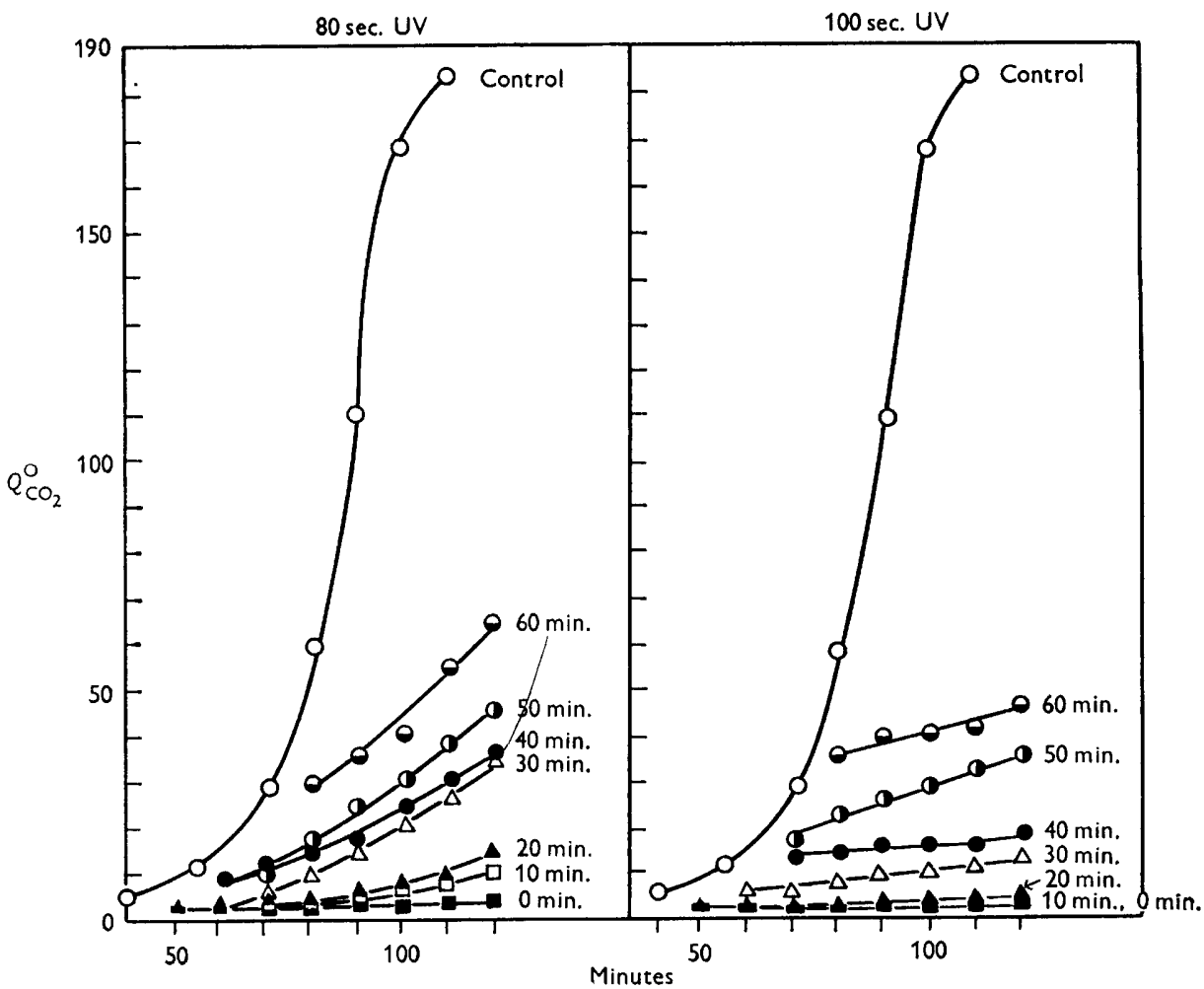

Fig. 4. Effect of the time of irradiation on the induced synthesis of $\alpha$-glucosidase. UV was applied for 80 or 100 sec. at various intervals after the addition of maltose. Enzyme synthesis was followed aerobically by the two-cup method.

UV applied during the active stage $(c .30 \mathrm{~min}$. later) only retards the rate of further synthesis. The rate of synthesis and eventual yield of enzyme are related to the time of irradiation. When dosages greater than 100 sec. are applied, this further synthesis can be prevented: under such conditions irradiation can be used to stabilize and measure the enzyme content (Spiegelman \& Halvorson, 1954).

Previous investigations (Halvorson \& Spiegelman, 1952; Halvorson, Spiegelman \& Hinman, 1955) showed that amino acid analogues (e.g. 0.01 м- $p$-fluorophenylalanine, 0.01 M-tryptozan) competitively inhibited not only the net utilization of the free amino acid pool but also inhibited $\alpha$-glucosidase synthesis when added simultaneously with the inducer. When 0.01 M-tryptozan 
was added at 20 or $40 \mathrm{~min}$. after the inducer, its ability to inhibit enzyme synthesis was markedly decreased (Fig. 5). Under these conditions tryptozan still inhibited the utilization of the free amino acid pool. Similar observations were made with parallel experiments in which $0.01 \mathrm{M}$ - $p$-fluorophenylalanine was added at intervals after the inducer. These results present convincing evidence that the active stage is also less resistant to inhibition by amino acid analogues than is the latent stage.

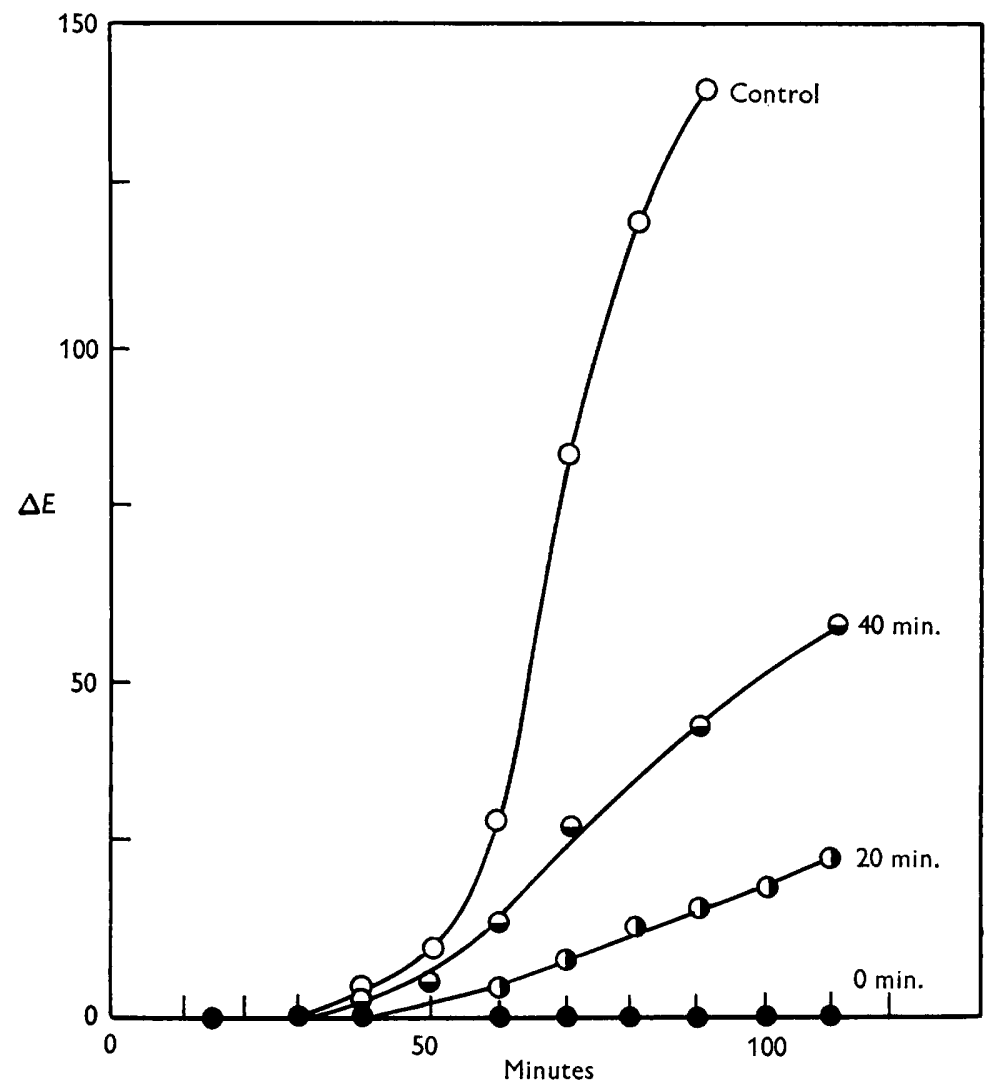

Fig. 5. Inhibition of enzyme synthesis by tryptozan. Tryptozan (final concentration of $0.01 \mathrm{M}$ ) was added with, and 20 and $40 \mathrm{~min}$. after, the addition of the inducer maltose. The increase in enzyme activity $\left(Q_{\mathrm{CO}_{2}}\right)$ over the control $(\Delta E)$ is plotted against time.

Experience over the past few years has shown that many metabolic antagonists are inactive against yeasts; fungicides, however, appear to be a promising class for analysis. Although many of these are energetic poisons, 2-pyridinethiol-1-oxide, at concentrations below $10 \mu \mathrm{g} . / \mathrm{ml}$., inhibits enzyme synthesis without affecting utilization of the substrate by a fully induced yeast cell. The inhibition cannot be annulled by a mixture of vitamins, amino acids, purines and pyrimidines or an RNA hydrolysate. Although the mode of 
action of this inhibitor is not understood, it is evident from the results in Table 3 that the latent stage of enzyme synthesis is more sensitive to this substance than is the active stage.

Table 3. Effect of 2-pyridinethiol-1-oxide on the induced synthesis of $\alpha$-glucosidase in yeast

The course of enzyme production was followed by the two-cup method in the standard Warburg apparatus at $30^{\circ}$. 2-Pyridinethiol-1-oxide $(0.5 \mu \mathrm{g} . / \mathrm{ml}$. $)$ was added at the indicated times after the addition of maltose. Enzyme activities, at the time of addition of the antagonist and at $180 \mathrm{~min}$., are recorded as $Q_{\mathrm{CO}_{2}}$.

\begin{tabular}{|c|c|c|}
\hline \multirow{2}{*}{$\begin{array}{c}\text { Time of } \\
\text { addition of } \\
\text { 2-pyridinethiol- } \\
\text { 1-oxide after } \\
\text { inducer }\end{array}$} & \multicolumn{2}{|c|}{ Enzyme activity } \\
\hline & $\begin{array}{c}\text { At time } \\
\text { of adding } \\
\text { antagonist }\end{array}$ & $\begin{array}{c}\text { At } \\
180 \mathrm{~min}\end{array}$ \\
\hline control & - & 300 \\
\hline 0 & 10 & 10 \\
\hline 15 & 10 & 60 \\
\hline 30 & 15 & 120 \\
\hline 45 & 30 & 145 \\
\hline 60 & 60 & 170 \\
\hline
\end{tabular}

\section{DISCUSSION}

The experiments of Kelner (1953) suggested a way for deciding whether various cellular constituents are active participants of the enzyme-forming system. Kelner found in Escherichia coli that a virtually complete separation of RNA and protein synthesis from DNA synthesis was brought about by low dosages of UV radiation. The present investigation uses this observation to study induced $\alpha$-glucosidase synthesis in yeast. Dosages of UV which inhibit DNA synthesis permit the synthesis of RNA, total protein and $\alpha$-glucosidase to continue. A similar separation is probably indicated by the results of $\mathrm{X}$-ray irradiation in yeast (Barron et al. 1953) and in tumour cells (Klein \& Forssberg, 1954).

Similar separations were observed in other experiments with Escherichia coli. When DNA synthesis was abolished, either by the use of sulphur mustards (Sher \& Mallette, 1954; Pardee, 1954), or proflavine (Drs Gros \& Spiegelman, 1954 ; unpublished results), there was little effect on induced enzyme synthesis. Employing a thymineless mutant of $E$. coli, Cohen \& Barner (1954) and Spiegelman et al. (1955) showed induced synthesis of xylose isomerase and $\beta$-galactosidase, respectively, in the absence of added thymine. In contrast, metabolic blocks leading to uracil and adenine deficiencies and to inhibitions in RNA synthesis resulted in the formation of little or no enzyme in the absence of the required metabolite (Pardee, 1954; Spiegelman et al. 1955). Experiments of this type indicate that synthesis of protein and induced enzyme is not coupled with DNA synthesis, although the presence of DNA may still be essential.

The present results, where the inhibition by varying doses of UV irradiation of total RNA synthesis (Fig. 1) and of ${ }^{32} \mathrm{P}$ (Table 1) and ${ }^{14} \mathrm{C}$ (Table 2) incor- 
poration into RNA runs parallel with the inhibition of enzyme formation (Fig. 2) and amino acid incorporation (Fig. 3), favour the hypothesis that RNA actively participates in protein synthesis. Further evidence linking RNA and induced enzyme synthesis was provided by Spiegelman et al. (1955) who found that enzyme synthesis was arrested when the nucleotide pool in the wild types or in pyrimidineless or purineless mutants of yeast was depleted; the subsequent addition of purines and pyrimidines restored not only RNA but also enzyme-forming capacity. Similar results were also observed with Escherichia coli.

Although the synthesis of new enzyme molecules may require continued RNA synthesis, it is not clear whether the positioning of an amino acid in a protein molecule per se need involve RNA synthesis. The recent demonstration of a soluble protein fraction which accelerates amino acid exchange (Hoagland, 1955) stresses the necessity for distinguishing between net synthesis and exchange reactions in incorporation experiments.

In addition to the approach described above for analysing the nature of the enzyme-forming system in induction, an insight into this problem can also be gained by examining the existence and properties of the stages of enzyme synthesis in yeast. The increase in enzyme activity during induction in yeast, whether plotted on a time basis or as a Monod plot $(\Delta E$ against $\Delta M)$, is invariably preceded by a lag period (Halvorson \& Spiegelman, 1955; unpublished results). This lag period is also associated with an increased sensitivity to UV irradiation, certain amino acid analogues and 2-pyridinethiol-1oxide. Concentrations of inhibitors or dosages of UV which completely inhibit enzyme synthesis when applied at the time of induction only retard the rate when applied during active enzyme synthesis. Both the rates and yields of enzyme synthesis are related to the time of this treatment.

At least two alternative explanations may be advanced to explain the early sensitive stage of enzyme synthesis: (i) this period may involve the formation from amino acids of a precursor of the enzyme, or (ii) the synthesis of a UVsensitive component of the enzyme-forming system, probably RNA. These two explanations need not be mutually exclusive.

In view of the specific and competitive nature of the inhibition and the parallel inhibitions of non-homologous amino acids (Halvorson \& Spiegelman, 1952; Halvorson, Spiegelman \& Hinman, 1955), the first alternative would require the synthesis of a precursor of the complexity of the enzyme itself. Its formation during the early stages would relieve a system depending on free amino acids and thus of sensitivity to amino acid analogues. The formation of this precursor may also be more UV-sensitive than is its conversion to enzyme:

$$
\text { AA } \underset{\substack{U V, \\ \text { analogues }}}{\longrightarrow} \text { precursor } \longrightarrow \text { enzyme }
$$

The existence of a precursor is also supported by a comparison of the kinetics of enzyme production with the kinetics of incorporation of ${ }^{14} \mathrm{C}$ free amino acid pool components into protein (Halvorson \& Spiegelman, 1955; unpublished results). A suspension of yeast cells was exposed briefly to exogenous 
glycine-1-14C (during which only the free amino acid pool was labelled) washed and induced to form $\alpha$-glucosidase in the absence of exogenous nitrogen. After $40 \mathrm{~min}$. of induction the ${ }^{14} \mathrm{C}$ incorporation into protein had reached its maximal value while $\alpha$-glucosidase induction was only one-third complete. These results suggest that the nitrogen for the remaining enzyme, which appeared after $40 \mathrm{~min}$., was derived from the free amino acid pool during the first $40 \mathrm{~min}$.

Until such a precursor can be isolated its existence must be considered as a speculation. The induction of $\beta$-galactosidase in Escherichia coli has been the only system thus far examined for the existence of a non-enzymic protein precursor. Although a non-enzymic protein fraction was detected which was immunologically related to the enzyme, it has been shown not to be a precursor of the enzyme (Rotman \& Spiegelman, 1954; Hogness, Cohn \& Monod, 1955).

An alternative possibility to explain the early sensitive stage in induction might be the existence of an essential UV-sensitive component of the enzymeforming system. This might be assumed to be either RNA itself or an RNAforming component of the enzyme-forming system. If RNA and protein synthesis are mutually dependent, then the amino acid analogues should also inhibit RNA synthesis and their effects would not necessarily favour the hypothesis of a precursor. The observation by Gale \& Folkes (1953) that in bacteria chloramphenicol can inhibit protein but not nucleic acid synthesis does not support this view. However, it is not clear at the present time whether RNA synthesis in yeast is normally dependent upon protein synthesis. The present data also do not exclude the possibility that the sensitive stage involves both the formation of a precursor and the synthesis of a necessary component of the enzyme-forming system.

We wish to express our deep appreciation to Dr J. O. Lampen (Squibb Institute) for the supply of 2-pyridinethiol-1-oxide and Mr Manuel Rosenbaum for technical assistance in these studies. This investigation was aided by a grant from United States Public Health Service and a grant by the Phoenix Project at the University of Michigan. One of us (L.J.) held a United States Public Health Fellowship during the course of the work.

\section{REFERENCES}

Anderson, E. P. \& Aquist, S. (1953). A double precursor study of nucleic acid turnover in normal and regenerating liver. J. biol. Chem. 202, 513.

Barron, L. S., Spiegelman, S. \& Quaster, H. (1953). Enzyme formation in nonviable cells. J. gen. Physiol. 36, 631.

Borsook, H. (1955). Mechanism of protein synthesis. Oak Ridge Conference on Enzyme and Protein Structure. J. cell. comp. Physiol. In the Press.

Conen, S. (1950). The anion-exchange separation of ribonucleotides. J. Amer. Chem. Soc. 72, 1471.

Cohen, S. \& Barner, H. (1954). Enzymatic adaptation by a thymine-requiring mutant of E. coli. Fed. Proc. 13, 193.

Edmonds, M., Delluva, A. \& Wilson, D. W. (1952). The metabolism of purines and pyrimidines by growing yeast. J. biol. Chem. 197, 251.

Gale, E. F. \& Folkes, J. (1953). The assimilation of amino acids by bacteria 15 . Actions of antibiotics on nucleic acid and protein synthesis in Staphylococcus aureus. Biochem. J. 53, 493. 
Gale, E. F. (1955). From Amino Acids to Proteins. In Amino Acid Metabolism, p. 171, edited by McElroy, W. D. \& Glass, G. Baltimore: The Johns Hopkins Press.

Halvorson, H., Fry, W. \& Schwemmin, D. (1955). A study of the properties of the free amino acid pool and enzyme synthesis in yeast. J. gen. Physiol. 38, 549 .

Halvorson, H. \& Jackson, L. (1954). The effect of ultraviolet light on the induced synthesis of maltase in yeast. Bact. Proc. p. 117.

Halvorson, H. \& Spiegelman, S. (1952). The inhibition of enzyme formation by amino acid analogues. J. Bact. 64, 207.

Halvorson, H. \& Spiegelman, S. (1953). The effect of free amino acid pool levels on the induced synthesis of enzymes. J. Bact. 65, 796.

Halvorson, H., Spiegelman, S. \& Hinman, R. (1955). The effect of tryptophan analogues on the induced synthesis of maltase and protein synthesis in yeast. Arch. Biochem. Biophys. 55, 512.

Hershey, A. D. (1953). Nucleic acid economy in bacteria infected with bacteriophage T2. II. Phage precursors of nucleic acid. J. gen. Physiol. 37, 1.

Hershey, A. D., Dixon, J. \& Chase, M. (1953). Nucleic acid economy in bacteria infected with bacteriophage T2. I. Purine and pyrimidine composition. J. gen. Physiol. 36, 777.

Hoagland, M. (1955). Enzymatic mechanism for amino acid activation in animal tissue. Fed. Proc. 14, 73.

Hogness, D., Cohn, M. \& Monod, J. (1955). Induced synthesis of betagalactosidase in E. coli. Biochim. biophys. Acta, 16, 99.

Juni, E., Kamen, M., Reiner, J. \& Spiegelman, S. (1948). Turnover and distribution of phosphate compounds in yeast metabolism. Arch. Biochem. 18, 387.

Kelner, A. (1953). Growth, respiration and nucleic acid synthesis in ultravioletirradiated and in photoreactivated Escherichia coli. J. Bact. 65, 252.

KLeIN, G. \& Forssberg, A. (1954). Studies on the effect of X-rays on the biochemistry and cellular composition of ascites tumors. I. Effect of growth rate, cell volume, nucleic acid, and nitrogen content in the Ehrlich ascites tumor. Exp. Cell Res. 6, 211.

LuRia, S. E. \& Dulbecco, R. (1949). Genetic recombinations leading to production of active bacteriophage from ultraviolet inactivated bacteriophage particles. Genetics, 34, 93.

Pardee, A. (1954). Nucleic acid precursors and protein synthesis. Proc. nat. Acad. Sci., Wash. 40, 263.

Pollock, M. R. (1953). Stages in enzyme adaptation in Adaptation in micro-organisms. Symp. Soc. gen. Microbiol. 3, 150.

Roberts, R., Abelson, P., Cowie, D., Bolton, E. \& Britten, R. (1955). Studies of biosynthesis in Escherichia coli. Washington, D.C.: Kerby Lithographic Co.

Rotman, B. \& Spiegelman, S. (1954). On the origin of the carbon in the induced synthesis of beta-galactosidase in Escherichia coli. J. Bact. 68, 419.

Sher, H. I. \& MALLETTE, M. R. (1954). The adaptive nature of the formation of lysine decarboxylase in Escherichia coli. Arch. Biochem. Biophys. 52, 331.

Spiegelman, S. \& Halvonson, H. (1954). On the role of the inducer in the synthesis of maltase in yeast. $J$. Bact. $68,265$.

Spiegelman, S., Halvorson, H. \& Ben-Ishai, R. (1955). Free amino acids and the enzyme-forming mechanism. In Amino acid Metabolism, p. 124, edited by McElroy, W. D. \& Glass, G. Baltimore: The Johns Hopkins Press.

Swenson, P. A. (1950). The action spectrum of the inhibition of galactozymase production by ultraviolet light. Proc. nat. Acad. Sci., Wash. 36, 699.

Swenson, P. A. \& GIEsE, A. G. (1950). Photoreactivation of galactozymase formation in yeast. J. cell. comp. Physiol. 36, 369.

Umbreit, W., Burris, R. H. \& StaUfFer, J. F. (1949). Manometric Techniques and Tissue Metabolism, p. 190. Minneapolis: Burgess Publishing Co.

(Received 20 June 1955) 